Frrat Üniversitesi Sosyal Bilimler Dergisi

Firat University Journal of Social Science

Cilt: 24, Sayı: 1, Sayfa: 33-47, ELAZIĞ-2014

\title{
TEZKİRELERDE ADI GEÇEN KİLİSLİ DİVAN ŞAİRLERİ
}

\author{
Divan Poets of Kilis that Mentioned in The Tezkires
}

\section{Hasan ŞENER*}

\begin{abstract}
ÖZET
Yavuz Sultan Selim zamanında alınarak Osmanlı topraklarına katılan Kilis, Osmanlı döneminde Halep'e bağlı bir kazadır. Osmanlı devletinin birçok vilayetinde olduğu gibi Kilis’te de edebî bir ortam var olmuştur. Bu çalışmada edebiyat tarihimiz açısından birinci derecede önemli kaynaklar olan şu'ara tezkirelerinde yer alan Kilisli Divan şairlerinin tespiti ve bu vesile ile Kilis'in kültürel envanterinin ortaya çıarılmasına katkı sağlanması amaçlanmıştır.
\end{abstract}

Çalışmada Kilis’te doğup yetişmiş ve tezkirelere girme başarısı göstermiş divan şairlerine yer verilmiş, tezkirelerin verdikleri bilgiler ışığında hayatları, kişisel özellikleri, edebi kişilikleri, meslekleri/görevlerinden bahsedilmiş ve şiirlerinden örnekler verilmiştir.

Anahtar Kelimeler: Kilis, tezkire, divan şairi, divan şiiri.

\begin{abstract}
Kilis was conquered at the time of Sultan Yavuz Selim and it was made part of Ottoman land. In the Ottoman period Kilis was a county of Aleppo. Like many other city's of Ottoman Empire Kilis also had a literary atmosphere. In this study we aimed to determine the divan poets of Kilis that mentioned in the tezkires of poets which has the primary importance in our literary history and herewith to contribute to uncovering the cultural inventory of Kilis.

In this study, we worked on the divan poets who was born and raised in Kilis and succeeded to be a part of tezkires. In the light of information from the tezkires we discussed their lives, personal characteristics, literary personalities, jobs and duties and gave examples about their poems.
\end{abstract}

Key Words : Kilis, tezkires, divan poet, divan poetry.

Temelleri 13. yüzyılda atılan Anadolu sahası Klâsik Türk edebiyatının ilk temsilcileri arasında Sultan Veled, Ahmed Fakîh, Dehhanî ve Şeyyad Hamza'nın isimleri geçmektedir. Bunlardan Sultan Veled, Ahmed Fakîh ve Şeyyad Hamza daha çok dinî-tasavvufî alanda ürünler vermişken Dehhanî daha ziyade lâdinî konularda şiirler kaleme almıştır. Bu yönüyle Dehhânî, Divan edebiyatının Anadolu'daki kurucusu kabul edilir. 14. yüzyıl'ın ikinci yarısı ile 15. yüzyılın ilk yıllarında yaşayan Ahmedî, beylikler dönemi olarak adlandırılan bu dönemin önde gelen şairidir. Gülşehrî ve Âş̧1k Paşa ise 14. yüzyıl Anadolu'sunda yetişmiş önde gelen mutasavvıf şairlerindendir (Mengi 2005: 77-84). 15. yüzyılda Anadolu'da edebiyat büyük bir gelişme göstermiştir. Ahmed-i Dâi, Şeyhî, Ahmet Paşa, Necati, Cem Sultan gibi şairlerin yanında Süleyman Çelebi, Hamdullah Hamdi gibi güçlü mesnevi yazarlarının öne çıktığı bu dönemde, Divan edebiyatı artık kuruluş dönemini tamamlamış ve klâsik bir edebiyat görünümü kazanmaya başlamıştır.

Çelebi Mehmet dönemine kadar Osmanlı padişahlarının en büyük emeli, ülkenin topraklarını genişletmek olduğu için edebiyatla ilgilenmeye pek vakitleri olmamıştır (İnalcık 1996: 47; Uzunçarşı11 1990: 118; Şentürk 2009: 3). Devletin kuruluş yıllarında padişahlar genellikle savaşlarda, savaş hazırlıklarında, yeni bir devlet kurma uğraşında oldukları için şehirlerde ve saraylarında oturmak, şiirle ve edebiyatla uğraşmak, sanatkârlarla ilgilenmek firsatı bulamıyorlardı. Küçük çapta da olsa saray etrafindaki şairler topluluğu ilk defa Çelebi Mehmet ve Sultan II. Murat devirlerinde Edirne Sarayı etrafında meydana gelmiştir. Devletin merkezi İstanbul'a nakledilince

\footnotetext{
* Yrd. Doç. Dr., Fırat Üniversitesi İnsani ve Sosyal Bilimler Fakültesi, Çağdaş Türk Lehçeleri ve Edebiyatları hsener@firat.edu.tr, senerhasan@gmail.com
} 


\section{F.Ü. Sosyal Bilimler Dergisi 2013-24/1}

bu şairler topluluğu İstanbul sarayı etrafında kümelenmeye başlamış ve 15 . yüzyıl ortalarından sonra Türk edebiyatının merkezi İstanbul olmuştur (İpekten 1996: 15).

Ankara savaşından sonra Anadolu'da baş gösteren 13 yıllık fetret devri dışında sanatçılar daima devlet adamlarınca korunup kollanmıştır. İstanbul'da padişah sarayı ve devlet büyüklerinin konakları, taşrada da Edirne, Konya, Amasya, Manisa, Trabzon, Kütahya gibi sancak merkezlerindeki şehzade sarayları, paşaların ve beylerin konakları şairlerin izzet ve ikram gördükleri, iltifatlara mazhar oldukları mekânlar olmuşlardır ki bu mekânlar sadece şairlerin veya sanatçıların korunmasını sağlamamış aynı zamanda edebi muhitlerin oluşmasına da zemin oluşturmuştur ${ }^{1}$.

Devletin merkezi olan ve padişah sarayının bulunduğu Edirne ve İstanbul ile şehzadelerin eğitim merkezleri olan ve şehzade saraylarının bulunduğu yukarıda isimleri zikredilen sancak merkezleri dışında, Anadolu'da Rahmî-i Harpûtî, Hacı Hayri Bey, Mustafa Sabrî Efendi, Efendizâde Ali Haydar Bey gibi ismini saymadığımız birçok şairin yetiştiği Harput (bkz. Onur 1988); Divan edebiyatında Nâbî ekolü diye kendi ismiyle anılan bir çı̆̆ırın öncüsü olan Nâbî gibi bir şairi yetiştiren Urfa; kaside denilince akla ilk gelen isimlerden biri olan Nef' '̂́'nin yanı sıra birçok şair yetiştiren Erzurum; 40 kadar divan şairi yetiştirmiş olan Diyarbakır gibi Antep, Bağdat, Kastamonu, Konya, Tokat diye isimlerini arttırabileceğimiz ve birçoğunu burada zikretmediğimiz ${ }^{2}$ bazı illerde de -birer edebi muhit olmasalar da- edebî ürünlerin ortaya konduğu edebi ortamların veya edebiyat merkezlerinin oluştuğunu görüyoruz.

Kilis de İstanbul ve sancak merkezleri dışında, Anadolu'da bir edebi ortamın oluştuğu illerimizden biridir. Kilis ilindeki edebi ortama geçmeden önce Kilis hakkında kısa bir bilgi vermekte fayda vardır:

Bugün Güneydoğu Anadolu Bölgesi’nin batısında, kuzeyde Gaziantep ili güneyde ise Suriye sınırı ile çevrili olan Kilis, Yavuz Sultan Selim tarafından 24 Ağustos 1516 tarihinde Mercidabık Köyü civarında yapılan ve aynı adla anılan savaş sonucunda Osmanlı topraklarına katılmış ve Kanuni Sultan Süleyman zamanında Canbolad Paşa'ya ocaklık olarak verilmiştir. Osmanlı devleti döneminde Halep sancağına bağlı bir kaza merkezi olan Kilis, Vâlide Sultanlara hass ${ }^{3}$ olarak verilmiştir. Devletin güçsüz olduğu dönemlerde mütesellim ve mütegalibe denilen yerel derebeyleri tarafindan yönetilmiştir.

Osmanlı idaresine geçtikten sonra hızla imar edilen Kilis'te özellikle cami, tekke, hamam, kervansaray gibi binalar inşa edilmiştir. Evliya Çelebi'ye göre Kislis'te $30 \mathrm{cami}, 7$ medrese, 11 sıbyan mektebi, 9 çeşme, 11 han, 2170 dükkân, 3 hamam, 7 tekke, bir Mevlevihane (Evliya Çelebi 1935: 361); Kâmûsu'l-A'lâm'a göre Kilis'te 37 cami, 14 mescit, 8 medrese, 24 tekke, 1 Rüştiye ve 25 Sibyan Mektebi ve 5 hamam ... (Şemseddin Sâmî 1314: 3880); 1284 tarihli vilayet salnamesinde 34 cami, 2 mescit, 11 medrese, 35'i Müslüman 5'i Hristiyanlara ait olmak üzere 40 mektep; 1326 tarihli vilayet salnamesinde ise 37 cami, 14 mescid, 24 tekke, 8 medrese, 496 cilt kitaplı bir kütüphane, 1 rüşti mektep, 25 iptidai mektep (aktaran Konyalı 1968: 22-24) bulunmaktadır.

Bizim için han, hamam, dükkân ve kervansaray gibi yapılardan ziyade tekke, cami mektep ve medreseler önem arz ediyor. Çünkü Kilis’te bulunan tekke, cami, mektep ve medreselerin ${ }^{4}$ Kilisli âlim, şair ve mutasavvıfların yetişmesinde ve Kilis'te Klasik Türk edebiyatı kültürünün gelişmesinde çok büyük önemi vardır. Bu kültürün gelişmesinde edebî sohbetlerin yapıldığı odalar da göz ardı edilmemelidir. Biliyoruz ki "Kilis, 18. ve 19. yüzyıllarda güneyin en önemli Doğu ve İslam Bilimleri merkezlerinden biri olmuştur. Her mahallesinde birkaç camisi, her camisinde

\footnotetext{
${ }^{1}$ Geniş bilgi için bkz. Haluk İpekten (1996). Divan Edebiyatında Edebî Muhitler. MEB Yay. İstanbul.

${ }^{2}$ Geniş bilgi için bkz. Mustafa İSEN (2010), Tezkireden Biyografiye, Kapı Yayınları, İstanbul. S.169-182.

${ }^{3}$ Osmanlı devletinde, devletin büyüklerine ayrılan ve yıllık geliri yüz bin akçeden fazla olan arazı.

${ }^{4}$ bkz. Ahmet Turan HAZAR, Ulema ve Camileriyle Kilis Medreseleri. ttps://s3.amazonaws.com/kaynakca/a76742c77ef0-46e8-8ca0-7e9213dd1a29/173959.pdf.
} 
uzaktan yakından gelmiş öğrencilerle dolu medreseleri bulunan bu kent, elbette ki bilim adamlarının yanı sıra şairler de yetiştirecekti. O zamanlar, Kilis'te varlıklı kimselerin odaları vardı. $\mathrm{Bu}$ odaların bir kısmında oda efendilerine yaranmaya çalışanlar toplanır, dedikodu ederlerdi. Bir de seçkin kişilerin ve aydınların toplandıkları odalar vardı. Bu odalarda da günün bilimleri ve edebiyatı konuşulurdu" (Başçıllar ?: 3-4).

Kilisli şairler üzerine yapılan çalışmalara (Kadri 1932; Başçıllar ?) baktığımızda; Rûhî Efendi, Celal Paşa, Hâkî-i Kadîm, Meylî, Sağır Kâtip, Bekir Vahîd Efendi, Fasiha Hanım, Şeyh Abdullah Sermest, Müftü Hâkî Efendi, Merküpçü Rahmî, Nutkî, Hacı Abdunnafî Efendi, Mehmet Sezâî Efendi, Zihnî Baba, Abdullah Refet Efendi, Hacı Fazıl Efendi, Ahmet Âgah Bey, Lutfullah Hâzım, Muharrem Kemâl, Ahmet Muhtar Yavaşça, Hüsnü Efendi, Rıfat Bilge, Hâmi, Cezzaroğlu Hacı Ahmet, Mecit Dilmen, Ahmet Rami Atan, Kadri Timurtaş, Mazhan Tokuz, Sait Dilmen, Hafiz Kamil Kıdeyş, Ziya Bey (?-?) gibi şairlerin Dîvân edebiyatı kültürü çerçevesinde şiirler yazdığını görmekteyiz. Bu şairlerin kimi hiç Kilis'in dışına çıkmamış kimi ise Kilis doğumlu olup eğitimmemuriyet gibi çeşitli vesilelerle Kilis dışına çıkmışlardır. Ama her halükarda Kilis'in manevi havasını teneffüs etmiş ve bu kültürün yetiştirmiş olduğu sanatçılardır.

Kilisli Kadri ve Seyfettin Başçıllar'ın yanı sıra bazı kaynaklarda bu şairlerin birçoğunun, divan sahibi oldukları söylenmektedir. Örneğin Arif Hikmet tezkiresi Kilisli Rûhî’ den bahsederken “... on cüz'i mütecâviz divân-1 eş’ârı var imiş...'(Çınarc1 2007:63) diyerek bizi Rûhî Divanı'ndan haberdar etmektedir. Kilisli Muallim Rifat, Rûhî Efendinin mirasçılarına göndermiş olduğu bir mektupta ${ }^{5}$, Kilisli Rûhî Divânı'nı İstanbul'daki tüm kütüphanelerde aradığını ancak bulamadığını, eğer kendi ellerinde varsa bastırılmak üzere gönderilmesini talep etmişse de bir sonuca ulaşamamıştır. Yine Kilisli Bekir Vahîd Efendi ve Zihnî Baba gibi şairlerin dîvânlarının kütüphane kayıtlarında ${ }^{6}$ var olduğunu görüyoruz. İnanıyorum ki Kilis ilimizin değişik evlerinde yukarıda adları geçen veya geçmeyen birçok şairimizin dîvânları veya şiirlerinin toplandığı defterler mevcuttur. Ama bunlar gün yüzüne çıkmadığı için bir gün birçoğu gibi kaybolup gitmeye mahkûmdurlar.

Kilisli Divan şairleri hakkında bu güne değin yapılan en kapsamlı çalışma Kilisli Kadri'nin Kilis Tarihi' dir ${ }^{7}$. Bu eserde genel anlamda Kilis tarihi verildikten sonra kitabın ikinci bölümünde Kilisli âlim ve şairlerden bahsedilmekte ancak herhangi bir kaynak gösterilmemektedir. "Eserimizin ikinci kısmı yazılırken birçok müsskilatla karşılaşılmıştır. Tercüme-i hallerini tespite uğraştı̆̆ım Kilis âlim ve şairlerinin yaşadıklart zaman ve muhitteki ilmi şahsiyetlerini, edebî menkabelerini ve eserlerini layıkıyla tetkik icap ediyordu. Bunun için çok taharriyat yaptım. Mezar taşlarına kitaphanelere müracaat ettim. Şu noktayı şükranla kaydedeyim ki bu hususta birçok zevatın hatıralarından, bilgilerinden çok müstefid oldum." ifadelerinden, Kilisli Kadri'nin, eserini hazırlarken yazılı kaynaklardan ziyade hatıralardan daha fazla istifade ettiğini anlıyoruz. Yine de Kilis ile ilgili birçok bilgiyi günümüze aktardığı için Kilis kültür tarihi açısından oldukça önemli bir eserdir. Kilisli şairlerden bahseden ikinci eser Seyfettin Başçıllar'ın Kilisli Dîvân Şairleri Antolojisidir ${ }^{8}$. Bu eser de Kilisli dîvân şairlerine ait şiirlerin derlenip kayıt altına alınması hasebiyle önemlidir.

Bu çalışmayı yapmamızın temel nedenlerinden biri, bugüne kadar Kilisli divan şairleri ile ilgili ciddi anlamda ilmi bir çalışmanın olmaması; konu ile ilgili yapılan ve yukarıda isimlerini zikrettiğim yayınlarda ise edebiyat tarihimiz açısından birinci derecede önemli kaynaklar olan tezkirelere müracaat edilmemiş olmasıdır.

\footnotetext{
${ }^{5}$ Mektubun aslı tarafimdan görülmüş olup bir fotokopi nüshası elimde mevcuttur.

${ }^{6}$ Özer Şenödeyici’nin "Kilisli Ebu Bekir Vahîd Divançesi”" ismiyle yayınladığı Bekir Vahîd Dîvânçesi, Milli Kütüphane yazmaları 06 Mil Yz Hk 966 numarada “Mecmu'a-i Eş'ar” olarak kayıtlıdır (Şenödeyici 2012: 27); Kilisli Zihni Dîvânı, Milli Kütüphane EHT 1948 A 3968 numarada kayıtlıdır. Ancak bu eser Zihni-i Bayburdi ismine kayıtlı görünmektedir..

${ }^{7}$ Kilisli Kadrî (Kadri Timurtaş) (1932). Kilis Tarihi. Burhaneddin Matbaası. İstanbul

${ }^{8}$ Başcıllar, Seyfettin (Tarihsiz), Kilisli Divan Şairleri Antolojisi, Kilis Kültür ve Dayanışma Derneği Yay. İstanbul.
} 


\section{F.Ü. Sosyal Bilimler Dergisi 2013-24/1}

Araştırmamız sonucunda tezkirelerde Kilisli oldukları belirtilen toplam sekiz şair tespit ettik. Çalışmamızda haklarında bilgi verilen şairleri kronolojik bir sıraya tabi tutmayıp alfabetik olarak sıraladık. Şairlerle ilgili olarak tezkirelerde verilen bilgilerin özünü günümüz Türkçesine aktardıktan sonra olması muhtemel atlama, hata veya yanlış anlamaları gidermek için tezkirelerden aldığımız metinleri transkripsiyon alfabesiyle verdik. Şairlere ait şiir örnekleri bu transkripsiyonlu metinlerinde olduğu için ayrıca vermedik.

Çalışmanın evreni, tezkirelere girmiş Kilisli şairler ile sınırlı tutulmuş olup Kilisli bütün şairleri kapsamamaktadır.

\section{Fakrî Dede}

Tezkirelerde karşımıza çıkan en eski Kilisli divan şairi, aynı zamanda bir Mevlevî şeyhi olan Fakrî Dede'dir. Fakrî Dede hakkında bize bilgi veren Esrar Dede'nin Tezkire-i Şuarâ-yı Mevleviyye'sidir. Tezkireden edindiğimiz bilgiye göre asıl ismi Ahmet olan Fakrî Dede Kilis'te dünyaya gelmiştir. Doğum tarihi konusunda herhangi bir tarih verilmeyen Fakrî Dede'nin, Mevlânâ'nın yedinci nesil torunlarından Sultan Dîvânî hazretlerinin halifelerinden birinin oğlu olduğu zikredilmiştir. Fakrî Dede, Şeyh Ahmed-i Kârî hazretlerinin sohbetlerine katılmış ve onun meclisinde tahsil görmüştür. Meşrebi fakr ü fenaya yatkın olduğu ve tasavvufî anlamda tam bir arınmaya meyilli olduğu için arkadaşları arasında Fakrî adıyla anılmış ve bunu mahlas olarak kullanmıştır. Bir rivayete göre Şah İsmail-i Safevî meclisinde Sultan Ebu's-Seyf hazretlerinin oğulları olan Fûlâd Mirza ve Ulvân Mirza Sultan Selim Han ile Şâh İsmail arasındaki savaşta Sultan Selim Han tarafına geçip padişahın yüce eşiğine yüz sürerek ikisi de padişahın iltifatlarına mazhar olmuş ve İsmailiyye savaşlarının sona ermesinden sonra Halep'te iskân olunmuşlardır. Burada Sultan Dîvânî’nin sohbetlerinden feyizlenerek Mevlevîliğe gönül bağlamışlar ve Halep şehrinde bir Mevlevîhâne inşa etmişlerdir. Fakrî Dede bu tekkeye şeyh olarak görevlendirilmiştir. Fakrî Dede, 950/1543-44 civarında Halep'te vefat etmiştir.

\section{Esrar Dede'nin Tezkire-i Şu'arâ-yı Mevleviyye'sinde Faḳrî Dede}

\section{Faḳî Dede}

Nām-1 maḥmūdları Aḥmed ve mevlid-i vücūdları Kilīs nām belde olup Cenāb-1 Sulțān Dīvānī kuddise sırruhu'n-nūrānī hulefāsından bir zāât-1 sütūde-ṣıfătuñ naḩl-i nah̄illeri idiler ve ve Şeyh Aḥmed-i Ḳārī kuddise sırruhu'l-bārī ḥazretlerinüñ șoḥbetine yetişüp feyż-i mecāliseleriyle taḥ̣̂̄l-i maḳāmāt-1 seniyye ve meşrebleri faḳr ü fenā ve tecrīd-i tāmmeye mā'il olmag̉la beyne'l-iḩvān Faḳrī tahalluṣ olınmışlardur. Ḥikāyet olınur ki Şāh İsmāa îl-i Șafevī meclisinde Sulțān Ebū's Seyf ḳuddise sırruhu'n-nūrānī hạżretlerinüñ kerāmāt-1 bāhirelerinden oğulları Fūlād Mīr-zā ve 'Ulvān Mīr-zā vāṣll-1 devlet-i intibah olup șoñra Sulțān Selīm hān 'aleyhi'r-rahmeti ve'l-guefrānla muhārebe-i Şāh İsmā îlde bi'l-istīmān taraf-1 cüyūş(-1) derya-ḩurūş(-1) ehli's-sünneye dahīl ve 'atebe-i 'aliyye-i şehryārīye rūy-māl olup ikisi dahi mažhar-1 elțâf-1 nevaziş-i pādişāhī olduḳda melāhịm-i İsmā'iliyye indifā 'ndan șoñra Haleb'de iskân olınmışlardı. Ba 'dehū sebeb-i devlet-i tesennün̄̄leri feyz-i naẓar-1 Sulțān Dīvānī kuddise sırruhu's-Sübhānīden ser-zede olmag̉la maḥabbet-i Mevlevīleri kemālde olup bi'l-iştirāk belde-i Ḥaleb'de Mevlevīhāane bina idüp țaraf-1 āsitāne-i Hudāvendigārīden şeỵh niyāz olınduḳda 'azīz-i mütercemi hānḳ̄āh-1 mezbūra şeyh eylediler ve ol buk'a-i mübārekede țoḳuz yüz elli hụdūdunda intiḳāl buyurdılar. Bu gazel eșer-i tab'-1 țāb-nākleridür.

\section{Ġazel}

Minnet Hुudāya ey dil her dūna minnetüm yok

Üstüme dutmaz ise gerdūna minnetüm yoḳ

Oldum fenā mücerred derviş-i bī-nevāyam

Ḳısmet olan geliser hiç ḩ ${ }^{\mathrm{v} a ̄ n a ~ m i n n e t u ̈ m ~ y o k ̣ ~}$ 
İçëm şarāb-1 'aşḳı keyfiyyetüm müdāmī

Esrār ü berş ü ḥabb ü afyūna minnetüm yok

Tecrīd ile felekde oldum Mesīḥ-i sāāī

Mālıyla yire geçsün Kāāūna minnetüm yoḳ

'Aş̧ ị ile bulmışam ben ey Faḳrī ol nigārı

İsm ü du'ā vü siḥr ü efsuna minnetüm yoḳ (Esrar Dede :94b-95a; Genç 2000: 424-425)

\section{Hâkî}

Hâkî hakkında Fatîn Davud'un Hâtimetü'l- Eş'âr ve Mehmet Tevfik'in Kâfile-i Şu'arâ isimli tezkirelerinde bilgi bulunmaktadır. Ayrıca Muallim Naci'nin Esâmî (Kurnaz 1986: 307) ve Kilisli Kadri'nin Kilis Tarihi (Kadri 1932:176-177) isimli eserlerinde de Hâkî’ye yer verilmiştir.

Fatîn Davud ve Muallim Naci'nin bildirdiklerine göre döneminde kıt'a söylemekle şöhret bulmuş bir şair olan Hâkî'nin asıl ismi Mehmet'tir. Doğum tarihi bilinmemektedir. Kilis'te dünyaya gelmiş ve İstanbul'a giderek hâcegân sınıfına dâhil olmuştur. Daha sonra defterdar mektupçuluğuna memur olarak devlet adamlarına yakın olma firsatı bulmuşken Fatîn Davud'a göre 1172/1758-59'de, Muallim Naci'ye göre 1176/1762-63'da vefat etmiştir.

Hâkî hakkında bize en detaylı bilgileri Kilisli Kadri vermektedir. Buna göre Kilis'in edebiyat tarihinde önemli bir yer işgal eden, eserlerinde sade bir dil kullanan ve yazmış olduğu tarih manzumeleri sanat ve belagat itibariyle edebî bir kıymeti haiz olan Mehmet Hâkî Efendi, Davut Ağa-zâdelerdendir. 1171/1757-59 yılında Kilis'te doğmuştur. Uncu-zâde Hasan Efendi'nin derslerine devam ederek icazetname almış ve Hindioğlu Camii medresesinde ders vermeye başlamıştır. Fıtraten yüksek bir zekâya sahip olan Hâkî, herhangi bir mevzu hakkındaki düşüncelerini kolaylıkla şiire dökebilirdi. Âlimâne duruşu, ilmi, halka karşı yumuşak davranması büyük bir hürmet ve teveccühle karşılanan, yaradılış olarak hayırperver olan ve ihtiyaç sahiplerine yardım etmekten derin bir zevk duyan Hâkî, dîvânını tabettirmek üzere İstanbul'a giderek orada ikamet etmeyi tercih etmiş ve az zaman içinde fazıl ve kemal ile şöhret bulmuştur. Şöhreti o zamanki devlet adamlarının da dikkatini çekmiş ve takdim ettiği bir kıt'a ile meşhur Rağıb Paşa'ya intisap etmiştir. Paşanın teveccüh ve delaletiyle memuriyete tayin edilerek birtakım önemli vazifelerde bulunmuştur. Yapılan araştırmaya göre Hâkî 1248/1832-33 tarihinde vefat etmiştir (Kadri 1932: 176-177).

Bu kaynakların -verdikleri bilgilerdeki detaylar hariç tutulursa- ayrıldıkları tek nokta Hâkî’nin doğum ve ölüm tarihleri ile ilgili kısımdır. Şöyle ki: Fatîn Davud ve Muallim Naci, Hâkî’nin doğum tarihini vermemekte, ölüm tarihi olarak da Fatîn 1172/1758-59, Muallim Naci ise dört yıl farkla 1176/1762-63 yılını vermektedir. Kilisli Kadri ise bu iki kaynakta ölüm tarihi olarak verilen tarihlere yakın bir tarih olan 1171/1757-59 yılını Hâkî’nin doğum yılı olarak vermekte ve 1248/1832-33 senesinde vefat ettiğini söylemektedir. Daha net görülmesi için bu bilgiyi bir tabloda vermekte fayda vardır:

\begin{tabular}{|l|l|l|l|}
\hline & Fatîn Davud & Muallim Nâcî & Kilisli Kadri \\
\hline Doğum tarihi & - & - & $1171 / 1757-58$ \\
\hline Ölüm tarihi & $1172 / 1758-59$ & $1176 / 1762-63$ & $1248 / 1832-33$ \\
\hline
\end{tabular}

Kilisli Kadri ve Muallim Naci, Hâkî'nin Koca Rağıp Paşa'ya bir kıt'a sunduğunu ve ona intisap ettiğini zikretmektedirler. Eğer bu bilgi doğru ise -ki doğru olduğu kanaatini taşımaktayımKoca Rağıp Paşa 1176/1762-63 tarihinde vefat ettiğine göre (Kurnaz 1986: 238-240) Kilisli Kadri'nin vermiş olduğu doğum ve ölüm tarihlerinin doğru olma ihtimalleri bulunmamaktadır. Çünkü eğer Kadrî’nin dediği gibi Hâkî 1171/1757-58 yılında doğduysa Koca Rağıp Paşa öldüğünde ancak 5-6 yaşlarındadır. Dolayısıyla bu yaşta Koca Rağıp Paşa'ya bir kıt'a sunup görüşmüş olmaları mümkün görünmemektedir. 


\section{F.Ü. Sosyal Bilimler Dergisi 2013-24/1}

Ayrıca Arif Hikmet de Tezkire-i Şuarâ'sında Hâkî mahlaslı bir şairden bahsetmektedir. Doğum yeri ve tarihi hakkında herhangi bir bilgi vermediği Hâkî’nin hâcegân sınıfi şairlerinden olduğu ve 1172/1758-59 y1lında vefat ettiği bilgisini vermektedir (Çınarc1 2007: 48). Bu bilgiler Fatîn Davud'da verilen bilgiler ile örtüşmektedir. Eğer bu iki tezkirede bahsedilen Hâkî aynı kişi ise şairimizin 1172/1758-59 yılında ölmüş olma ihtimali artıyor.

\section{Fatîn Davud'un Hâtimetü'l- Eş‘âr'ında Hâkî}

\section{Mehmed Hâkî}

Kit'a

Kerem mukāta'ası tā zemān-1 Hātemden

Kalıp mezādda bir kimse olmayıp tālib

Kimin nukūd-1 'atāyāsı var onu alacak

Meger habāb-1 sadāret-penāh ola Rāgıb

Nāzım-1 Dīvān-1 hüner-mendi Mehmed Hākī Efendi beriyyetü'ş-Şām cānibinde kāin Kilis nām kasabada çehre-nümā-yı 'ālem-i vücûd olup Dersaādet'e bi'l-muvāsala sinıf-1 Hācegāna duhūl ile; Hāk ol ki Hudā mertebeni eyleye 'âlī mısra'ı meālince mütevāzi'āne hareket ve bi'l-āhire defterdâr mektubculuğu me' mūriyyetine nāiliyyetle karīn-i ricāl-i devlet olmuş iken bin yüz yetmiş iki senesi hilālinde rūh-1 pāki 'āzim-i sūy-i eflāk ve cesed-i derd-nāki dāhil-i zīr-i hāk olmuştur. 'Asrında kıt'a-gūlukda şöhret-şi'ār olan şu'arādandır (Sarıkaya 2007: 179; Çiftçi: 121).

\section{Muallim Naci’nin Esāmīsinde Hākī}

Kit'a söylemekte maharetle şöhret kazanmış bir şā irdir ki, Kilis kasabasında doğmuş ve İstanbul'a gelerek defterdar mektupçuluğuna kadar yükseldikten sonra 1176/1762-63'de vefat etmiştir. Koca Rağıp Paşa'ya dair şu kıt'ası meşhurdur.

Kerem mukata'ası tā zemân-1 Hātemden

Kalıp mezâdda bir kimse olmayıp tālib

Kimin nukūd-1 'atāyāsı var onu alacak

Meger habāb-1 sadāret-penāh ola Rāgıb (Kurnaz 1986: 307)

\section{Kâ'il}

Kâ'il hakkında Şefkat, Arif Hikmet, Es'ad Efendi, Silahdar-zade tezkireleri ve Mehmet Süreyya'nın Sicill-i Osmanîsinde bilgi bulunmaktadır. Ancak bu kaynaklarda verilen bilgiler şairin asıl ismi, doğum yeri ve nerede oturduğu ile sınırlıdır. Şairin ismi ve ikamet ettiği yer konusunda bütün kaynaklar aynı şeyi söylerken doğum yeri konusunda farklılık göstermektedirler. Adı geçen kaynaklarda belirtildiğine göre Kâ'il'in asıl ismi Mustafa'dır ve İstanbul'da ikamet etmektedir. Doğum yeri ile ilgili hususa gelince, Şefkat tezkiresinin iki nüshasında "Kilili'dir, İstanbul sakinlerindendir" ifadesi kullanılırken bir diğer nüshada ${ }^{10}$ "Kilili'dir" yerine "Kilisli' dir" ifadesi kullanılmıştır (Önder 2006: 213). Silahdarzade tezkiresi de (vr.56a) Kâ'il'in Kilis'te doğduğunu kaydetmektedir. Arif Hikmet, Kâ'il'in Akkirmanlı (Çınarcı 2007: 95), Es'ad Efendi ise Galatalı (Oğraş 2001: 151) olduğunu söyler. Mehmet Süreyya ise İstanbullu ve III. Selim devri şairlerinden olduğunu belirtmektedir (Akbayır 1996: 858). Tezkirelerin vermiş olduğu bu kısa bilgilerden Kâ'il'in nereli olduğunu kesin olarak söylemek mümkün görünmemektedir. Ama Kilis veya bugün Ukrayna sınırları içinde kalan Kili'de ${ }^{11}$ doğup İstanbul'a sonradan geldiği kesin görünmektedir. Kaynaklardaki bu karışıklığın "Kili" ve "Kilis" isimleri arasındaki benzerlikten kaynaklandığı kanaatindeyim.

\footnotetext{
${ }^{9}$ Bayezid Devlet Kütüphanesi, Veliyüddin Efendi, No: 3427. , 80 varak (161 s.); İstanbul Üniversitesi Merkez Kütüphanesi, No: 3916, 83 varak, 1933.

${ }^{10}$ Millet Kütüphanesi, Ali Emirî Tarih, No: 770, 106 varak (210 s.).

${ }^{11}$ Arif Hikmet'de bahsedilen Akkirman da bugün Ukrayna sınırları içinde kalmıştır.
} 


\section{Şefkat'in Tezkire-i Şuarâ'sında Kâ'il}

Mușțafā Efendi. Kilisli'dir. İstanbul sākinlerindendir. Bu gazeller onundur.

Çün oldu hâl-i cihânbâzi-i karaca çepiş

Ne yerde yârı bulursan efendi pekçe yapış

Takılsan ardına ol âfitâbın etme şitâb

Ip1l ıpıl geriden yürü sâye gibi apış

Sunulmaz ol şehe hîç 'arz-1 hâl açıkdan

Seyirci şekline gir kûşenin birine sepiş

İnanmam ey rakîb eyler isen da'vî-i dîn

Büt-i cemâle a kâfir nedir o sende tapış

Sapıtmasın sözü boș i’tizârı dinleyemem

Bizi görünce uzakdan nedir o kasdi sapış

Garaz kol atmak ise boynuna zerâfetle

Biraz çagır çabala tekye-i gam içre tepiş

Revâ mı böylece nâ-puhte kalmak 'âlemde

Tenûr-1 'aşk u muhabbetle Kâ'il âsâyiş

Bu gazel de onundur:

Derlerse sana gülşen-i hüsn öyledir eved

Yâ saçların degil mi benefșe demed demed

Gül-penbe şâlı kaftanını giyme sevdigim

Feryâda salma sen beni bülbül gibi meded

Yaşın on altı on yedide çünki ey güzel

Ol yaş içün döküldü gözüm yaşı bî-'aded

Ben haftalarca seyr edemem vech-i pâkini

Hâce dedikleri eşegin bahtına hased

Allahdan isterim ki sayılsın kaburgas1

Yelpâzenin ki oldu yüzün seyrine o sed

Pây-zen rakîb kaç ki seni etmesin pā-sar

Kurtulmasın kürekden o kâfir ile'l-ebed

Başında Kâ'ilin n'ola esse kavak yeli

Tâkat gelir mi sende var iken o serv-kad

Bu gazel de onundur:

Nüvâziş etse de dil-ber inanma ey gönül dekdir

Ki onun bahr-i zu'munda her âdem şaşkın ördekdir 
Ne mümkin yâra çift olmak zerâfetle nezâketle Dahı kundakdan ol 'ayyâr fenn-i hîlede dekdir

Şeb-i firkatda kanlar yutmalı bir mâha 'âşıksan Şafak anlarsın ey dil sana bir rengîn örnekdir

Erir 'âşık olan nâm-1 dil-ârâyı işitdikde

Nigîn-i yâr onunçün defter-i 'uşşâkdan hakdır

Nice âyîne-i dil münkesirdir dest-i cevrinden

Sakın ey şîşe-i hâtır onun sengîn-dili pekdir

Onun sık sık cefâsından figân etmekdedir dil hep

Müyesser olsa da geh geh vefâsı lîk seyrekdir

Dürûg-1 va'de-i vuslatla yârı ittihâm etdim

Demiş insâf edip Kâ'il belî kavlinde gerçekdir

Bu gazel de onundur:

Yâr ile dehânı ne içün çünki cedelli

Dersem o dehâna ola nâ-büd mahalli

Ebrûları kec çalmadadır işime dâ'im

Her hâldedir bana onun hâli halelli

Sevdâsına dil düşse de ol mûy-miyânın

Nâ-kâm ola çagıdır o belden katı belli

Nâlem göricek sundu lebin agzıma dil-ber

Zenbûr-1 figânım n'ola olduysa 'aselli

Endîşe-i vasl eyler iken deste dayandım

Tâ kasr-1 tefekkür ola gâyetle temelli

Tir tir tenimin ditredigin seyr edicek yâr

Bir hande usûlüyle edip dedi yalelli

Hep vaz'-1 firîbânesidir sâde dilâna

Bak pîre-zen-i çerhe giyer her gece telli

Meydân-1 tecerrüdde çenâr ile tutuşma

$\mathrm{Bu}$ 'arsada bir merddir ol haylîce elli

Kā'il tutalım âhiri merg oldu bu 'aşkın

Hîç kimse vefât eylemez illâ ki ecelli (Kılıç ?: 124-126; Önder 2006: 213-215)

\section{Arif Hikmet'in Tezkiretü'ş-şu'arâ'sında Kā'il}

Akggermāni Mușțafa Efendi. (Tezyil) Tezkkire-i Şefḳat'te külliyetli olduğu mesțūr dört 'aded gazel muharrerdür. Bu gazel andan me' huuzdur ${ }^{12}$ (Çınarcı 2007: 95)

\footnotetext{
${ }^{12}$ Yukarıda Şefkat tezkiresinde örnek verilen
} 
Tezkirelerde Adı Geçen Kilisli Divan Şairleri.

\section{Es'ad Mehmed Efendi’nin Bağçe-i Safâ-Endûz’unda Ḳā’il}

\section{Kâ'il (Galatalı Mustafa Efendi)}

Müstaḳim-zāde'nin Mecellesi ḳavl-i mücmelince mūmā-ileyhin vakti şu arāsından Galatalı Mustafa nām bir zātdır (Oğraş 2001: 151).

\section{Resîm}

Resîm Hakkında bilgi aktaran tek tezkire Şefkat-i Bağdadi'nin Tezkire-i Şu'arâ'sıdır. Bu tezkireye göre asıl ismi Hüseyin olan Resîm, yüksek rütbeli kadılardandır. Edirne rütbesiyle Halep’ten azledilmiştir. Kilisli Hüseyin Resîm Efendi ismiyle bilinmektedir.

\section{Şefkat'in Tezkire-i Şu'arâ'sında Resîm}

İsmi Hü̈seyn'dir. Mevâlî-i kirâmdan. Edirne pâyesiyle Ḥaleb'den ma'zûl idi. Kilisî Hüseyn Resîm Efendi demekle ma'rûf idi. Bu gazeller onundur.

Gazel:

Serv-i gülzâr-1 İrem şimşâd-1 tarf-1 cû mudur

Şem '-i bâlâ-yı tecellî ḳâmet-i dil-cû mudur

Kāabe kavseyn-i melâhat şeh-per-i Cibrîl-i hü̈sn

Mushaf-1 hüsn ü bahâya raḥle yâ ebrû mudur

Ser-hat-i meşk-i cünûn yâ ser-nüvişt-i 'âşıân

Sâye-i zülf-i perîşân yâ nikâb-1 rû mudur

Yâ nişân-1 bûse ger yâ merkez-i pergâr-1 hüsn

Ahter-i subh-1 bahâ yâ hâl-i 'anber-bû mudur

Kârbân-1 'ömr-i refte yâ gubâr-1 müşg-i çîn

Kâkül-i müşgîn külâle yâ kemend-i mû mudur

Cevher-i âyîne-i hüsn ü safâ şekl-i hilâl

Mevc-i bahr-i nâz u çîn-i cebhe-i nîgû mudur

Yâ belâ-yı nâgehân yâ tîg-i bî-dâd-1 kazâ

Ejder-i pür-zehr yâhud gamze-i câdû mudur

Ebr-i gülzâr-1 cinân yâ sâye-bân-1 şâh-1 hüsn

Ka'be-i hüsn ü cemâle perde-i pâk-bû mudur

Yâ perî-zâde beşer-sîmâdır ol vahşî Resîm

Pîşezâr-1 hüsnde yâ beççe-i âhû mudur

Ve lehu:

Yeter mülâzemet-i bezm-i kesret eyleyelim

Biraz da kûş̧e-i vahdetde râhat eyleyelim

Nüvâziş etse de dil-ber inanma ey gönül dekdir

Ki onun bahr-i zu'munda her âdem şaşkın ördekdir

matla'lı gazeli örnek olarak vermiştir. Tekrar olmasın diye yazılmadı. 


\section{F.Ü. Sosyal Bilimler Dergisi 2013-24/1}

'İlâc vâkı'a pîş-ez-vukû' bâyed gerd

Safầ-yı hâtır ile terk-i ülfet eyleyelim

Zebân-1 'asrı tamâm anladık hemân biz de

Hulûsuna göre halkın sadâkat eyleyelim

Ne iddi'â-yı vefâsı ne bâr-1 minneti var

'Adâvet eyleyene biz muhabbet eyleyelim

Şarâb-1 kâm ile ser-germ-i neş'e olmazsak

'Akîk-i sabr ile def'-i harâret eyleyelim

Çekip bu gerdiş-i câm-1 hevâdan el demidir

Şumâr-1 sübha-i eşk-i nedâmet eyleyelim

Misâl-i şeb-nem edip terk-i bûy u reng Resîm

Nezâresine bu bâgın kanâ'at eyleyelim (Önder 2006: 130-131; Kı1ıç ?: 66-67)

\section{Rıfkî}

Rıfkî hakkında bilgi veren tezkire Şeyhü'l-İslam Arif Hikmet Beyin Tezkiretü'ş-Şu'arâ'sıdır. $\mathrm{Bu}$ tezkirede zikredilen bilgilere göre Rıfkî, Kilis’te doğmuştur. Sefer yıllarında babasıyla birlikte Adana şehrine hicret etmiş ve ilim tahsiliyle uğraşmış ve uzun yıllar bu şehirde ikamet etmiştir. Daha sonra Misır ve Rum taraflarına bir miktar seyahatten sonra yine Adana şehrine dönmüş ve orada 1197/1782-83 y1lında vefat etmiştir. Surûrî, şairin ölümüyle ilgili olarak şu tarih beytini yazmıştır.

Bekâda Hak ide Rıfkı fakire en'âmı (1197)

Arif Hikmet, Rıfkî ile ilgili şu bilgileri de aktarmaktadır: Ağlar görünüşlü, köse sakallı, esmer alınlı, ucûbe yüzlü, yüksek zekâya sahip, parlak zihinli, âlim ü fazl-1 kemâl gazabından tab'i, bilmeceye meyilli bir zât imiş. Beş cüz mikdarı divanı varmış. Güzel talik yazabildiğinden daima dîvânını tahrîr ile meşgul olurmuş (Çınarcı 2007: 61).

\section{Arif Hikmet'in Tezkiretü'ş-şu'arâ'sında Rıfkî \\ Rıfkî}

Keliz'de tevellüd idüp șefer sininde pederiyle Adana şehrine hicret ve taḥsil-i 'ilme iştigalle nice zaman anda iḳāmet ve ba 'de Misır ve Rum caniblerine bir miḳdar seyahatden șoñra yine Adana şehrine rica at ve anda țoḳsan yedi senesi 'azim-i cennet etmiştir. Tārīhli Surūrī: "Beḳāda Hak ide Rıfḳı faḳire en āmı (1197).” Giryeü'l-manzar, köse lihye, esmer alun, 'ucūbe-peyker, reisü'l-zekāya șāhịib, żihn-i śaḳı, 'ālim ü fażl-1 kemal gażābından țab 'i, eh-hāaciye mā'il bir żāt imiş. Beş cüz' miḳdārı dīvānı var imiş. Latīf ta 'lik hattı olduğundan dā'ima divanını tahrir ile iştigàā imiş (Çınarcı 2007: 61).

\section{Rûhî}

Şeyhü'l-İslam Arif Hikmet Bey'in Tezkiretü'ş-şu'arâ'sında bilgi verdiği bir diğer Kilisli şair Rûhî'dir. Arif Hikmet Bey'in bildirdiğine göre Rûhî'nin asıl ismi Mustafa'dır. Kilis'te doğmuştur ve doğum yeri olan Kilis'te 1213/1798-99 yılında vefat etmiştir. Surûrî, Rûhî’nin ölümüyle ilgili olarak şu tarih beytini yazmıştır.

Cihândan Mustafa Rûhî Efendi göçdü cennete

Yine Arif Hikmet Bey'in bildirdiğine göre Rûhî, âlim ve sâlih bir kişidir. Yetenekli bir şairdir. Vefat ettiğinde yaşı sekseni geçmiştir. Dönemindeki vezirlerden hürmet görmüştür. Kendisi o 
bölgede Halep gibi bazı şehirleri gezdiğinde bölge halkı ziyadesiyle izzet ü ikram ederlermiş. Pendi Attar üzerine Rûhu'ş-Şurûh adında büyük bir şerhi ve on cüzü içeren şiir dîvânı varmış.

Rûhî hakkında en geniş bilgiyi Kilisli Kadri'de (Kadri 1932: 150-155) bulmaktayız. Kadri'ye göre Mustafa Rûhî, Çelebizâdelerdendir. 1133/1720-21 tarihinde doğmuştur. Çekmeceli-zâde'nin derslerine katılmış ve ondan icazetname aldıktan sonra Güllü Camii medresesinde dersler vermeye başlamıştır. Türkçe, Arapça ve Farsçayı iyi derecede bilen Rûhî, bu üç dilde şiir yazmaya muktedirdir. Şair olduğu kadar bir ilim adamı olan Rûhî'nin yazdığı şiirlerde hakimâne ve Fuzuliyâne parçalar vardır.

Kadri, Rûhî'nin Ruhu'ş-şurûh (Attar'ın Pend-nāme'sinin şerhi), Divan, Ta'bir-nāme, İnşa ve Kur'an-1 Kerim Havassı olmak üzere beş eserinden bahsetmekte ve bunların matbu olmadığını, yazma nüshalarının çocuklarında olduğunu söylemektedir. ${ }^{13}$

\section{Arif Hikmet'in Tezkiretü'ş-şu'arâ'sında Rûhî}

\section{Rûhî-i Kelizî}

İsmi Mustafadır. Maskat-1 re'si olan Keliz'de bin iki yüz on üç senesi irtihal-i dār-1 beḳā etmiş. Tārīhn-i Surūrī:

\section{Cihāndan Mustafā Rūḥi Efendi göçdü cennete}

'Ulemādan ve șulehādan bir pīr-i sāl-horde imiş. Şāa ir-i māhir imiş. Ḥinn-i vefâtında sinni semānīni güzāran itmiş. Ekșer āmed-şod eden vüzerādan mükerrem olup kendü dahi ol havālīde Haleb gibi ba'żı memāliki devr ettikde ahālisi ziyāde 'izāz ü ikrām ederler imiş. Așār-1 yarā'e-i berā'e șanā'ilerınden Pend-i Ațtāar üzerine Rūhüu'ş-şurūḥ nām bir şerḥ-i 'azīmi ve on cüz'i mütecāviz dīvān-1 eş’ārı var imiş. Așārından bu tārīh-i ra'nāya dest-res olduk:

Gece sā'at ikide zelzele yıḳdı Şâm'1 (1173) (Çınarcı 2007: 63).

\section{Mehmed Emin Vahîd Paşa (Re'îsü'l-küttâb)}

Mehmet Emin Vahid Paşa hakkında Fatîn Davud'un Hâtimetü'l- Eş'âr'ında bilgi verilmektedir. Ayrıca Franz Babinger de eserinde ${ }^{14}$ Vahîd Paşa'ya yer vermiştir. ${ }^{15}$ Fatîn'e göre Mehmet Emin Vahid Paşa, Kilis'te doğmuş ve çocukluğunda annesiyle birlikte İstanbul'a gitmiştir. Gençlik yıllarında bir müddet maliye kaleminde çalışmıştır. Sultan III. Selim zamanında zecriyye ${ }^{16}$ başkâtipliğine ve daha sonra zecriyye muhasallığı memuriyetine ve 1221/1806-07 senesinde mevkufat mansıbına daha sonra özel görev ile Paris'e gönderilmiştir. Paris'ten döndükten sonra 1224/1809-10 yılı ortalarında defterhane-i amire emanetine ve bir ay geçmeden rikâb-1 hümâyun dâhilinde olmak üzere makam-1 riyaset-i küttâba getirilmiş, üç ay sonra bu görevden alınıp sürgün olarak Kütahya şehrine gönderilmiştir. Bir buçuk yıl sonra af edilerek tophane-i amire nezaretine ve 1227/1812-13 y1lında tersane-i amire emanetine getirilmiştir. Bir yıl sonra bu görevden azledilmiştir. 1229/1813-14 yılında muhalefat memuriyetiyle Tekke kazasına gönderilmiştir. Sonra uhdesine vezirlik rütbesi tevcih edilerek Tekke ve Hamîd sancaklarına ve birkaç sene geçtikten sonra da Girit adasında bulunan Hanya muhafizlığına görevlendirilmiştir. Bundan sonraki on üç sene zarfinda sahip olduğu vezirlik rütbesi üç defa uhdesinden alınmış ve her seferinde başka bir yere sürülmek suretiyle tekrar kendisine verilmiştir. Önce Hanya muhafızlığından Sakız adasına,

\footnotetext{
${ }^{13}$ Ne yazık ki tüm aramalarımıza rağmen Ruhu'ş-şurûh hariç Rûhî’nin eserlerine ulaşılamamıştır. Kilisli Muallim Rıfat Bilge de Rûhî’nin çocuklarına gönderdiği bir mektupta, tabetmek üzere Rûhî Divanı'nı sormuşsa da bir netice alamamıştır. Ruhu'ş-şurûh 'un nüshaları kütüphanelerde mevcut olup Cumhur Ün tarafindan doktora tezi olarak çalışılmıştır (bkz. Ün 2007).

${ }^{14}$ Bkz. Franz Babinger (1982). Osmanlı Tarih Yazarları ve Eserleri (Çev. Coşkun ÜÇOK). Kültür ve Turizm Bakanlığı Yayınlar1. Ankara. s. 377-378

${ }^{15}$ Franz Babinger'e göre Vahîd Paşa'nın “babası İstanbullu, annesi Kilisli' dir. Annesinin Hırıstiyan olması muhtemeldir. Kilis'te doğmuştur. Annesi sonradan İstanbul'a gelip Baltacı ile evlenmiş ve bundan böyle kendisi İstanbullu olarak gösterilmiştir.” (Babinger 1982: 377)

${ }^{16}$ zecriyye: alkollü içkiler vergisi
} 


\section{F.Ü. Sosyal Bilimler Dergisi 2013-24/1}

ikinci kez Sakız adasından Karahisar'a ve üçüncü kez 1242/1826-27 y1lında Halep eyaletinden ${ }^{17}$ Bursa'ya sürülmüştür. 1243/1827-28 yılı sonlarında Çanakkale boğazındaki Kal'a-i Sultaniye'ye ${ }^{18}$ denk olan ve Eski İstanbulluk diye adlandırılan yerin muhafızlığına ve birkaç ay içinde de Bosna eyaletine tayin edilmiştir. ${ }^{19}$ Bosna'ya gidemeden 1244/1828-29 yılı başlarında Eski İstanbulluk'ta vefat etmiştir.

Mehmet Emin Vahid Paşa'nın devrin tek insanı demeye layık yüce şanlı bir vezir olduğunu ifade eden Fatîn, onun Minhâc-1 Remât isminde ok atıc1lığına dair bir eserinin var olduğunu, tezkiresine aldığı örnek şiirlerden başka herhangi bir şiirine ulaşamadığını ${ }^{20}$ ve Kütahya şehrinde bir kütüphanesinin olduğunu söylemektedir.

Fatîn, Mehmet Emin Vahid Paşa'nın Kilisli olmasından dolayı bazı kişilerin bazen haseb ve nesebce hakkında uygun olmayan sözler sarf ettiklerinden, kendisinin "şehriyyül asl” olduğunu ilan etmek amaciyla

"Ferzend-i Sitânbulum ferzend-i Sitânbul"

mısraını birçok kez teleffuz ettiğinin Zeyl-i Sefinetü'r-Rüesâ'da yazılı olduğu bilgisini de aktarmaktadır.

\section{Fatîn Davud'un Hâtimetü'l- Eş'âr'ında Mehmet Emîn Vahîd Paşa (Re'isü'l-küttâb)}

\section{Emîn Vahîd Paşa}

Beyt

Yârin visâle rağbeti olmuş çi fâ'ide

Harf-i recâ ziyânım ile âşinâ değil

Beyt

Keşf-i râz etmez salâbetkâr olan kable’l-fenâ

Yanmadıkça 'ûd sırr-1 bûyın etmez âşikâr

Beyt

İltizâm eyleyenin mazbutı keyfince gerek

'Arak-âşâma Sakız bâde-keşâna Erdek

Beyt

Bu degirmân-i fenânın elem-i devri amân

Dâne-i 'aklımı un etti elekden eledi

Nâzım-1 ma'ârif-pîrâ re'îsü'l-küttâb Mehmed Emîn Vahîd Paşa Kilis nâm memleketde kademnihâde-i sâha-i vücûd olup tufûlliyyeti esnâsında validesiyle berâber Dersa'âdet'te nakl ü güzer eyleyip 'unfuvân-1 şebâbetinde 'atîk bâb-1 defterîde vâki' mâliye kalemine bir mûddet mûdâvemetle Sultân Selîm Hân-1 Sâlis hazretlerinin zamân-1 saltanatlarında zecriye baş kitâbetine ve ba'dehu zecriye muhasıllıgı me'mûriyetine ve bin iki yüz yirmi bir senesi mevkûfât mansıbına ve o esnâda me'mûriyet-i mahsûsa ile Paris cânibine 'azîmet ve 'avdetinde ki iki yüz yirmi dört senesi evâsıtında defterhâne-i 'âmire emânetine ve bir mâh mürur etmeksizin rikâb-1 hûmâyûn

\footnotetext{
${ }^{17}$ Halep eyaletine nereden geldiği konusunda herhangi bir bilgi verilmemektedir.

${ }^{18}$ Bugünkü Çimenlik Kalesi.

19 Babinger, “...1244/1828'de çiftçilik yapmak üzere Bosnaya giderken, daha gideceği yere varmadan yolda Çanakkale'de 2 sefer 1244 yani 14 ağustos 1828'de ölmüştür.” diyerek tam tarih vermektedir.

${ }^{20}$ Babinger'e göre Vahid Paşa'nın okçuluk sanatı hakkındaki "Minhāc-i rumāt" isimli eserinin yanısıra İngiltere elçisi Robert Adair ve kendisi arasında 1223/1809'da Çanakkale'de akdedilmiş olan İngiliz-Türk barışının görüşmeleri hakkındaki "Risale-i Vahîd Efendi" adı verilen kısa bir risale yazdığını ve 1237/1822 yılı Sakız olaylarını anlatan ve Vak'a-i Sakız yahut Târîh-i vak'a-i cezire-i Sakız isimli tanınmış ve basılmış bir eserinin olduğunu belirtmektedir (Babinger 1982: 378).
} 
dâhilinde olmak üzere makãm-1 riyâset-i küttâba mükârenet ve üç mâh mürûrunda riyâset-i merkûmeden mûfârakatla menfiyyen medine-i Kütahya'ya 'azimet ve bir buçuk sene müddet ikãmetden sonra 'afv ü itlâkı vukû'ına mebnî tekrâr Dersa'âdet'te bi'l-muvâsala tophâne-i 'âmire nezâritine ve iki yüz yirmi yedi senesi tersâne-i 'âmire emânetine mevsûl olup senesini itmâm ile ma'zûl olduğu hâlde iki yüz yirmi dokuz senesi muhallefât me'mûriyetiyle Teke kazasına i'zâm ve o aralık 'uhdesine rütbe-i vezâret bi't- tevcîh Teke ve Hamîd sancaklarına ve birkaç sene mürûrunda cezîre-i Girid'de kâ'in Hanya muhafızlığına me'mûren hükümrân-1 'izz ü ihtişâm buyrulmuş ise de ber-muktezâ-yı şîve-i kadr on üç sene zarfinda hâ'iz olduğu rütbe-i vezâret üç def'a 'uhdesinden sarf u tahvil olunarak her birinde bir mahalle nefy ü iclâ ve kuvve-i tâli' hasebiyle tekrâr vezâreti kendine terk ü ibkā buyrulup def'a-i ûlâsında mezkûr Hanya muhâfızlığından cezîre-i Sakıza ve def'a-i sâniyesinde cezîre-i merkûme muhâfızlığından Karahisar sâhip nâm mahalle ve iki yüz kırk iki senesi def'a-i sâlisesinde Haleb-i şehbâ eyaletinden mahrûsa-i Bursa'ya nefy ü tagrîb ile iki yüz kırk üç senesi evâhirinde Bahr-i Sefîd Boğazında Kal'a-i Sultâniye mukãbilinde vâki eski İstanbulluk ta'bîr olunan mahallin emr-i muhafazasına ve birkaç mâh zarfinda Bosna eyâletine me'mûr ve tâyîn buyurulmuş iken eyâlet-i merkûme cânibine 'azîmet-i müyesser-gerde-i Cenâb-1 Rabb-i Ehadiyyet olmayıp iki yüz kırk dört senesi evâ'ilinde mahall-i mezkûre işbu memer-gâh-1 mâsivâdan füshat-sarây-1 bekãya 'azm ü rihlet eylemiştir. Müşârûn-ileyh vahîdü'l-asr denmeye şâyân bir vezîr-i 'âlî-şân olup eser-i kalem-i mu'ciz-rakamı olmak üzere remy-i kavsa dâ'ir Minhâc-1 Remât isminde bir 'adet risâle-i mu'teberisi ve âsâr-1 hayret-dişârından olarak medine-i Kütahya'da bir bâb kütübhâne-i muhtasarası vardır. Bâlâda muharrer ebyâtından başka eş'ârı manzûr-1 'âcizî olmamıştır. Müşârün-ileyhin Kilisli olması cihetiyle haseb ü nesebce hakkında ba'zı gûne zikri gayr-1 câ'iz sözler tefevvüh ve isnâd olunmuş olduğundan şehrü'l-asl olduğunu i'lân eylemek garazıyla, nazm:

Ferzend-i Sitanbulum ferzend-i Sitanbul

mısra'ını birçok zamân evrâd-ı zebân eylemiş olduğu Zeyl-i Sefînetü'r-rüesâda mastûr ve mukayyettir (Sarıkaya 2007 690-692; Çiftçi ?: 431-432).

\section{Celal Pașa}

Celâl Paşa'nın Kilisli mi yoksa Diyarbakırlı mı olduğu tartışma konusudur. İbnü'l-Emin Mahmut Kemal İnal'e göre Celal Paşa'nın babası Çeteci Abdullah Paşa ile birlikte Kilis'ten Diyarbakır'a gidip yerleşmiş ve Celal Paşa Diyarbakır'da doğmuştur. Mahalli âlimlerden, özellikle de Küçük Ebubekir Efendi'den ilim tahsil etmiş, babası vefat edince annesi ile küçük kardeşini Kilis'teki akrabalarının yanına göndermiş, kendisi Diyarbakır'da kalarak bir müddet daha ilim tahsil ettikten sonra 1198/1783-84'de İstanbul'a gitmiş, Divan-1 Hümayun kalemine girmiş, liyakatini çekemeyenler hiddetinden şikayetçi olunca kalemden ayrılmış, 1204/1789-90'de Maden Emini Yusuf Ziya Paşa'nın divan katibi olmuş, devlet kademesinde birçok görevde bulunmuştur. ${ }^{21}$ Mora isyanını bastırmak için 12 Rebiülevvel 1238 (28 Kasım 1822)'de Rumeli Ser-askeri unvanıyla Rumeli eyaletine atanmış ve yoldayken vefat etmiştir (Cunbur 1999: 299-302). Kilisli Kadri'ye göre ise Celal Paşa Kilis'te doğup büyümüş, ilk tahsilini Ulu Cami'de yapmış ve daha sonra İstanbul'a gitmiştir. Kadri, Celal Paşa'nın Kilisli olduğunu ispat için onun Bosna eyaletine tayin olunduğu sırada Kilis’teki kardeşine bir mektup ve birkaç kitap göndermesini, gönderdiği bu mektubun dört yerinde Kilis için “beldemiz" ifadesini kullanmasını, Kilis'e kitap göndermek suretiyle onun Kilis ile fiili alakasını delil göstermekte ve Celal Paşa'nın vefatından sonra Kilis'teki akrabalarına maaş bağlanmasının kendisinin bu fikrini teyit ettiğini belirtmektedir (Kadri 1932: 166). İleri sürülen her iki görüşte de Celal Paşa'nın aslen Kilisli olduğu düşüncesi ortaya çıkıyor.

Celâl Paşa yüksek görevlerde bulunmuş bir devlet adamı olmanın yanı sıra güçlü bir şair ve usta bir nesir yazarıdır. Celâl Paşa'nın müsveddelerini toplayarak Münşe'ât-1 Celal ismiyle bir araya getiren Vak'a-nüvis Sa'dullah Enverî-zâde Enver Efendi “... fünûn-1 edebiyede sâhibü’l-

${ }^{21}$ Ayrıntı için bkz. Cunbur 1999: 299-302 


\section{F.Ü. Sosyal Bilimler Dergisi 2013-24/1}

nisâb, elsine-i selâsede şi'r ü inşâya mu’tedir" (aktaran Cubur 1999: 301) diyerek Celal Paşa'nın edebî yönüne dikkat çekmiştir.

Celâl Paşa hakkında Son Asır Türk Şairleri'nde oldukça geniş bilgi bulunduğu ve bahsi geçen eser yayınlandığı için fazla detaya girmeden bir gazelinden örnekle bu bahsi bitirmek istiyorum.

\section{Gazel}

Cemālinden cüdā düşmek benim cānā celālimdir

Celālinle bana cevr eylesen mahzā cemālimdir

Cemālin pertevinden aks alur āyine-i kalbim

Seni bir lahza şāhım görmemek ammā celālimdir

Celālin bezm-i hüsnünde bana bir özge hâlettir

Şehād-i gamzen olsam bilmiş ol cānā cemālimdir

Cemālin şem'ine cem 'oldılar üftādeler ammā

Benim pervane-veş per yaktığım hālā celālimdir

Celāl'in bu perişan hāline rahmeyle sultanım

Esīr-i zülfünüm cevr ü gamın zīrā cemālimdir (Cunbur 1999: 302)

\section{SONUÇ}

Tezkirelere bağlı olarak yaptığımız bu çalışmada ismi tezkirelerde zikredilen sekiz dîvân şairi tespit ettik. Tezkirelerdeki bilgiler doğrultusunda şairlerin hayatları, meslekleri ve edebî kişilikleri hakkında bilgi verdik.

Çalışmanın sonunda Kilis’te birçok dîvân şairinin yetiştiğini ancak tezkirelere girme başarısı göstermiş şair sayısının az olduğunu gördük. Buna, Kilisli dîvân şairlerinin Kilis dışına çıkmamış olmaları sebep olarak gösterilebilir. Çünkü tezkirelere girmiş Kilisli şairlerin bir şekilde Kilis dışına çıktığı ve herhangi bir devlet kademesinde görev aldığını görüyoruz. Fakrî Dede ve Resîm Halep'e; Rifkî, Adana ve Misır'a; Hâkî ve Kâil, İstanbul'a; Vâhîd Paşa ve Celâl Paşa İstanbul'a ve daha sonra da görev icabı Osmanlının değişik vilayetlerine gitmiş Kilisli dîvân şairleridir. Kilis’te doğup Kilis'te yaşadığı halde tezkirelere girme başarısı göstermiş tek Kilisli şair, Rûhî’dir. Bu da Kilisli Rûhî’nin Kilis dışında tanındığını ve okunduğunu gösterir.

Bu güne değin Kilisli Ebu Bekir Vahîd (bkz. Şenödeyici 2012) dışında Kilisli dîvân şairleri üzerine yapılmış ilmî bir çalışma bulunmamaktadır. Tezkirelere girmiş veya girmemiş Kilisli dîvân şairleri üzerine yapılacak geniş çaplı ilmî çalışmalar, Kilis'in tarihine ait birçok bilgi, belge ve kültür unsurlarını ortaya çıkaracağından başta Kilis olmak üzere Türk kültür tarihine büyük katkı sağlayacaktır.

\section{KAYNAKÇA} İstanbul.

Akbayır, Nuri (Hzl) (1996). Mehmet Süreyya, Sicilli Osmanî, C.III., Tarih Vakfı Yurt Yayınları.

Babinger, Franz (1982). Osmanlı Tarih Yazarları ve Eserleri (Çev. Coşkun ÜÇOK). Kültür ve Turizm Bakanlığı Yayınları. Ankara.

Banarlı, Nihat Sami (1987). Resimli Türk Edebiyatı Tarihi, Milli Eğitim Basımevi. İstanbul.

Başcıllar, Seyfettin (Tarihsiz), Kilisli Divan Şairleri Antolojisi, Kilis Kültür ve Dayanışma Derneği Yay. İstanbul.

Cunbur, Müjgan (hzl) (1999). İbnü'l-Emin Mahmud Kemal İnal, Son Asır Türk Şairleri. C.I., Atatürk Kültür Merkezi Başkanlığı Yayınları. Ankara 
Çınarcı, M. Nuri (2007). Şeyhü’1-İslam Arif Hikmet Bey'in Tezkiretü'ş-şu'arâsı ve Transkripsiyonlu Metni, Gaziantep Üniversitesi Sosyal Bilimler Enstitüsü, Basılmamış Yüksek LisansTezi. Gaziantep.

Çiftçi, Ömer (hzl). Fatîn Davud, Hâtimetü’l- Eş‘âr (Fatîn Tezkiresi) http://ekitap.kulturturizm.gov.tr/ dosya/1-219117/h/metin.pdf

Esrar Dede. Tezkire-i Şu’arā-yı Mevleviyye. Sülaymaniye Ktp. Halet Efendi eki 109.

Evliya Çelebi (1935). Seyahatname. Cilt IX., Devlet Matbaası. İstanbul.

Genç, İlhan (hzl.) (2000). Esrar Dede, Tezkire-i Şuarâ-yı Mevleviyye, Atatürk Kültür Merkezi Yayınları. Ankara.

İnalcık, Halil (1996). Büyük Osmanlı Tarihi, Ankara.

İpekten, Haluk (1996). Divan Edebiyatında Edebî Muhitler. MEB Yay. İstanbul.

Kılıç, Filiz (Tarihsiz). Tezkire-i Şu'ara-yı Şefkat-i Bağdādī. http://ekitap.kulturturizm.gov.tr/dosya/1219127/h/metinsb.pdf

Konyalı, İbrahim Hakkı (1968). Abideleri ve Kitabeleriyle Kilis. Fatih Matbaası. İstanbul. Ankara

Kurnaz, Cemal (hzl) (1986). Muallim Naci, Osmanlı Şairleri. Kültür ve Turizm Bakanlığı Yayınları.

Mengi, Mine (2005). Eski Türk Edebiyatı Tarihi. Akçağ Yayınları. Ankara.

İsen, Mustafa (2010). Tezkireden Biyografiye, Kapı Yayınları, İstanbul.

Onur, Naci (1988). Harputlu Divan Şairleri (İnceleme-Seçme). İzzetpaşa Vakfi Yayınları. Elazı ̆̆.

Oğraş, Rıza (2001). Es'ad Mehmed Efendi ve Bağçe-i Safâ-Endûz’u. İnceleme-Metin. KTB Yayınları http://ekitap.kulturturizm.gov.tr/dosya/1-219113/h/bahce.pdf

Önder, Murat (2006). Şefkat ve Tezkire-i Şu'ârâsı. Yüksek Lisans Tezi. Afyon Koca Tepe Üniversitesi. Sosyal Bilimler Enstitüsü. Afyonkarahisar.

Sarıkaya, Orhan (2007). Tezkirecilik Geleneği İçerisinde Fatîn Tezkiresi. Yüksek Lisans Tezi. İstanbul Üniversitesi Sosyal Bilimler Enstitüsü. İstanbul.

Silahdar-zâde Mehmet Emin. Silahdar-zâde Tezkiresi. Millet Kütüphanesi. Ali Emiri. Tarih. No:795

Şemseddin Sâmī (1314). Kâmûsu'l-A'lâm (Tıpkıbasım). C.V. Mihran Matbaası. İstanbul.

Şentürk, Ahmet Husrev (2009). XVI. Yüzyıl Anadolu Sahası Şu'arâ Tezkireleri Işı̆̆ında Bursalı Şairler. Basılmamış Yüksek Lisans Tezi. Dumlupınar Üniversitesi Sosyal Bilimler Enstitüsü. Kütahya

Şenödeyici, Özer (2012). Kilisli Ebu Bekir Vahîd Divançesi. Kömen Yayınları. Ankara.

Uzunçarşılı, İ. Hakkı (1990). Büyük Osmanlı Tarihi, İstanbul, Türk Tarih Kurumu Yay. Ankara

Ün, Cumhur (2007). Kilisli Mustafa Rûhî Efendi’nin Ruhu'ş-şurûh u. Doktora Tezi. Trakya Üniversitesi Sosyal Bilimler Enstitüsü. Trakya. 
